\title{
A Nuisance Law Approach to the Problem of Housing Abandonment
}

\author{
Building abandonment has become a critical problem in many \\ cities. ${ }^{1}$ The abandonment of a building may adversely affect nearby \\ residents, accelerating the decline of the neighborhood and triggering \\ further abandonment. ${ }^{2}$ The impact of abandonment is particularly \\ marked in transitional areas-aging but stable neighborhoods usually \\ located on the periphery of slums. ${ }^{3}$ This Note argues that nuisance
}

1. The problem of abandonment has prompted considerable concern and commentary. E.g., W. Grigsby \& L. Rosenburg, Urban Housing Policy (1975) thereinafter citcd as Grigsiy]; G. Sternlieb \& $R$. Burchell, Residential Abandonment: The Tenement LANDlord Revisited (1973) [hereinafter cited as Sternlieb]; United States Departaient of Housing and Urban Development, Abandoned Housing Research: A Compendium (1973) [hereinafter cited as HUD]; Sternlieb, Abandonment and Rehabilitation: IWhat is to be Done?, in Papers Submitted on Housing Production, Housing Demand, and Developing a Suitable Living Environment, to Subcomm. on Housing Ponels of the House Comm. on Banking and Currency, 92d Cong., 1st Sess. 315-82 (1971) [hereinafter cited as House Papers]; Hearings on Bills Relating to Housing and Urban Development Before the Subcomm. on Housing and Urban Affairs of the Senate Comm. on Banking and Currency, 91st Cong., 2d Sess. (1970) [hereinafter cited as Senate Hearings]; N.Y. Times, Apr. 12, 1976, at 1, col. 6-7. The most common measure of abandonment used in these studies is the housing unit-a house, apartment, group of rooms, or single room intended to be a separate living quarter. See Burlau of the Census, Current Housing REPORTS: Housing VACANCIES 5 (Ser. H-111-75-5, Apr. 1976).

In the period between 1965 and 1968, owners in New York City alone abandoned nearly 100,000 housing units, more than were destroyed in over 20 years of slum clearance. Kristof, Housing: Economic Facels of New York City's Problems, in AGENDA FOR A City: Issues Confronting New York 305-11 (L. Fitch \& A. Walsh eds. 1971). Abandonment in New York City is continuing at a rate of 21,000 to 50,000 units a year. N.Y. Times, Apr. 12, 1976, at 1, col. 6. As many as one million units, out of a housing stock of approximately three million units, may be abandoned by the end of 1980 . Note, Building Abandonment in New York Cily, 16 N.Y.L.F. 798, 798-99 (1970).

In 1970, there were 10,000 abandoned housing units in St. Louis and 30,000 in Philadelphia. HUD, supra at 5. Baltimore was losing 4,400 units annually by 1972 estimates; Chicago, about 1,800 units. Edson, Housing Abandonment-The Problem and $a$ Proposed Solution, 7 Real Prop., Prob. \& Tr. J. 382 (1972). Washington, D.C., Boston, Cleveland, and Houston also have abandonment problems. Senate Hearings, supra at 803-04. Even newer urban areas, such as Los Angeles, have experienced some difficulties with abandonment. GRIGSBY, supra at 157.

In addition to eroding the urban housing stock, abandonment shrinks the property tax base and thus drains a major source of city revenue. N.Y. Times, Apr. 12, 1976, at 50, col. 1; id., Feb. 8, 1976, \$ 8, at 1, col. 2.

2. Sec note 19 infra. Abandonment occurs in sound as well as deteriorated neighborhoods. See GrIGSBY, supra note 1, at 206 ("[C]oncern over abandonment arises precisely because it appears in so many instances to precipitate rather than follow decay, striking solid structures in physically sound neighborhoods, not just those buildings and areas where deterioration has almost run its course." (footnote omitted)); HUD, stupra note I, at 9, 10, 12; N.Y. Times, Apr. 12, 1976, at 1, col. 6. See also Nachbaur, Empty Houses: Abandoned Residential Buildings in the Inner City, 17 How. L.J. 3 (1971).

3. It is difficult to define transitional areas more precisely. New York City's Neighborhood Preservation Program, which focuses on transitional areas, uses four criteria to designate neighborhoods for attention: (l) whether the housing stock is essentially sound 
suits against abandoning owners should be encouraged, $*$ and it proposes means to facilitate such actions. Imposition of liability on abandoning owners should slow the deterioration of the urban housing stock and improve the allocation of resources devoted to housing, without regressive distributional effects.

\section{Abandonment: The Problem}

Buildings generally are abandoned because they no longer are viable investments. ${ }^{5}$ Rent control $^{6}$ and reduced demand for urban housing ${ }^{7}$ keep revenues down while obsolescense, problem tenants, ${ }^{8}$

but financial institutions and property owners have begun to withdraw financing; (2) whether the housing stock has deteriorated but needs only moderate rehabilitation; (3) whether certain housing indicators recently have signaled an adverse trend; and (4) whether unique neighborhood characteristics (e.g., tenant groups, parks, public transportation) reinforce the stability of the area. Weitzman, Neighborhood Preservation in New York Cily, 3 Fordhax Uru. L.J. 425, 432-33 (1975). New York City neighborhoods with transitional area designations-"neighborhood preservation arcas" and "preventivc rehabilitation areas"-represented about $40 \%$ of the city's housing stock in 1965 . Id. at 429 n.22.

Hughes and Bleakly have delineated five stages of neighborhood decline. J. HucHes \&. Bleakly, URBan Homesteading 50-52 (1975). Isolated incidents of abandonment commonly occur in Stage 2 and Stage 3 neighborhoods, "areas where the level of urban degeneration has not gone [very] far and where there are significant pockets of deeplyrooted citizenry who can serve as an anchor for the maintenance of whole neighborhoods." Id. at 55 .

4. In only one reported case was an abandoning owner held liable in nuisance for the decline in a neighbor's property value. Puritan Holding Co. v: Holloschitz, 82 Misc. $2 \mathrm{~d}$ 905,372 N.Y.S.2d 500 (Sup. Ct. 1975). The plaintiff owned a recently renovated apartment building in an urban renewal area where property values were rising. When a building across the street was abandoned, the value of the plaintiff's apartment building dropped approximately $\$ 30,000$. $I d$. at 907,372 N.Y.S.2d at 502 . The court, recognizing the power of a single abandoned building to destroy a neighborhood, found the building a nuisance and rendered a default judgment for the plaintiff. Id., 372 N.Y.S.2d at 502. Sec N.Y. Times, Sept. 11, 1975, at 45 , col. 1 .

5. Not all owners are motivated by economic considerations. Resident owners are less likely to capitulate to the economic pressures that normally causc abandonment. Sternlieb's study of Newark found that $46.3 \%$ of non-abandoning owners resided in their buildings, whereas only $11.9 \%$ of abandoning owners had lived in the buildings that they abandoned. STERnLieb, supra note 1 , at 306 .

6. Nrw York City Rand Institute, Rental Housing in New York Gity: Confronting IHL CRISIS (I. Lowry cd. 1970) [hercinafter cited as RAND Study]; Senate Hearings, supra note $I$, at 805.06.

7. This reduced demand results from a long term trend toward urban decentralization spurred by decreasing transportation costs, a general preference for suburban living, and a steady rise in income. See GRIGSBY, supra note 1 , at 197-98 (effects of preference for suburban living and rising incomes); R. MUTh, Cities ANd Housing 117-21 (1969) (on role of decreasing transportation costs). As their incomes rise, families move away from the city leaving their former homes for occupancy by lower income families. As poorer people move into these homes, housing demand near the center of the city diminishes. E. Milis, Urban Economics 176-78 (1972).

8. See GrigsiY, supra note 1, at 201. 
code enforcement, ${ }^{9}$ and general economic conditions increase costs of operation. ${ }^{10}$ As profitability decreases, the market values of these buildings decline. Since ready buyers are unavailable, ${ }^{11}$ owners become locked in. They lose their incentive to maintain services and undertake necessary repairs. Finally, they abandon. ${ }^{12}$

The abandoning owner, however, usually does not consider the costs his actions impose on his neighbors. An abandoned building produces various types of "negative externalities"13 which interfere with the use and enjoyment of nearby property. A vacant building is a frequent target of vandals. ${ }^{14}$ It may shelter criminal activity and harbor derelicts and drug addicts who threaten the security of nearby residents. ${ }^{15}$ In addition, an abandoned building may become a fire ${ }^{10}$ and

9. Strict enforcement of housing codes may accelerate abandonment by forcing landlords to bear additional costs. On the other hand, when the housing codes are not enforced, maintenance declines and abandonment eventually may follow. Compare Nachbaur, supra note 2, at 39-43. wilh Freilich, Housing Code Enforcement and Abandonment: An Impossible Choice for the Courts, 7 URb. LAw. ix, xiii (1975), and Project, Abandonment of Residential Property in an Urban Context, 23 DEPAUL L. REv. 1186, 1196 (1974). But see GrigsiY, supra note 1, at 158 ("In only a few instances were there any indications that abandonments of basically sound structures followed directly the city's enforcement of the housing codc.") See generally Abbott, Housing Policy, Housing Codes and Tenant Remedies: An Integration, 56 B.U. L. REv. 1, 66-83 (1976) (examining the impact of strict enforcement in stable and deteriorated areas).

10. For example, increases in the cost of heating oil have led directly to increased abandonment. N.Y. Times, Sept. 29, 1974, § 8, at 1, col. I; id., Feb. 26, 1974, at 1, col. 7.

11. HUD, supra note 1 , at 8 . Even in transitional areas, buyers are difficult to find. See Nourse \& Phares, The Impact of FHA Insurance Practices on Urban Housing Markets in Transition-The St. Louis Case, 9 URB. L. ANN. 111, 112 (1975).

12. Abandonment may also be triggered by a sudden adverse event. Fire or vandalism, for example, may necessitate expensive repairs. Rather than risk a large investment, the owner may walk away. GrigsBY, supra note 1 , at 207-08. In addition, many buildings are abandoned in anticipation of government takings by eminent domain. See id. at 157; Note, Condemnation Blight and the Abutting Landowner, 73 М.н. L. REv. 583, 581 (1975).

13. A "negative externality" is a direct adverse effect on one person's welfare "arising as an incidental by-product of some other person's or firm's activity." E. Mishan, Cost-Benefit ANalysis 101, 109 (1971).

14. See Foster v. City of Detroit, 254 F. Supp. 655, 660 (E.D. Mich. 1966), aff'd, 405 F.2d 138 (6th Cir. 1968); GrigsBy, supra note 1, at 176-78; Comment, Properly Abandonment in Detroit, 20 Waync L. Rev. 845, 866 (1974). A former Chicago building commissioner reportedly observed that buildings in Chicago are "fit only for the wrecking ball" within two wecks after vacancy. Senate Hearings, supia note 1 , at 821 .

15. Nearly $4 \%$ of major reported crimes in Newark in 1971 occurred in abandoned buildings-10 murders, 15 rapes, and almost 150 incidents of assault and battery. In addition, vacant buildings were the sites of nearly 200 incidents of malicious mischief and 100 narcotics offenses. STERNLIEB, supra note 1, at 150. See Senate Hearings, supra note 1 , at 890 (indicating similar situation in Boston).

16. Abandoned buildings are inherently fire-prone and present an inviting target for arsonists. In Boston, $18 \%$ of all structural fires in 1969 occurred in racant buildings. Senate Hearings, supra note 1 , at 880 . More than $21 \%$ of severe fires in Newark in 1970 and 1971 occurred in vacant residential buildings, yet less than $5 \%$ of buildings in the city were vacant. Sternles, supra note 1, at xxi-xxii. New York City recently suffered a rash of such fires. See, e.g., N.Y. Times, June 8, 1975, $\$ 4$, at 5, col. 1; id., May 20, 1975, at $50, \mathrm{col} .1$. The risk of fire is so great that the presence of one abandoned structure in a neighborhood of clapboard buildings may lead to cancellation of insurance for the entire block. Senate Hearings, supra note 1 , at 831 . 
health hazard. ${ }^{17}$ Less tangibly, it may inflict aesthetic and psychological injuries. ${ }^{1 s}$ Furthermore, an abandonment in a transitional area may create expectations of neighborhood deterioration, thereby depressing real estate values and precipitating further abandonment. ${ }^{18}$

Despite the serious damage caused by abandonment, city governments have afforded neighbors of abandoning owners little protection. Statutory restrictions and administrative programs designed to mitigate the harmful effects of abandonment ${ }^{20}$ have been, on the whole, in-

17. J. HuGHes \& K. BleAkLY, supra note 3 , at 56 . An abandoned building may become a breding place for rats and flies. See City of Chicago v. General Realty Corp., 133 Ill. App. 2d 662, 664, 665, 273 N.E.2d 712, 713, 714 (1971), cevt. denied, 406 U.S. 945 (1972). Furthermore, children may bc hurt playing in a structurally unsafe abandoned building. See Beauchamp v. New York City Hous. Auth., 12 N.Y.2d 400, 190 N.E.2d 412, 240 N.Y.S.2d 15 (1963); Runkel v. City of New York, 282 App. Div. 173, 123 N.Y.S.2d 485 (1953). Or an abandoned building may collapse and injure neighbors. See Marshall. Putnam Farm Bureau, Inc. v. Shaver; 12 IIl. App. 3d 402, 299 N.E.2d 10 (1973); Rapkin v. City of New York, 139 N.Y.S.2d 215 (Sup. Ct. 1955).

18. Abandoned buildings are often cyesores. For pictures of such buildings, sce SternlifB, supra note 1, at 50 passim, and Senate Hearings, supra note 1, at 932-33, 936-38.

For a discussion of the psychological damage that may stem from abandonment, sce Note, Pliladelphia's Urban Homesteading Ordinance: A Poor Beginning Toward Reoccupying the Urban Ghost Town, 23 Buffalo L. Rev. 735, 752 (1974).

19. A component of the value of real property is the quality of surrounding property. Deterioration of sound housing thus stems in part from owners' fears that they will be unable to recoup their full investments on maintenance and repairs because neighbors will permit nearby buildings to deteriorate. Weitzman, supra note 3 , at $441-42$. See Davis \& Whinston, The Economics of Urban Renewal, 26 LAw \& CoNrrmp. Pron. 105, 108-10 (1961). But see E. Milus, supra note 7, at 173-74.

The snowballing process of deterioration has been described by a former official of New York City's Housing and Development Administration:

$[W]$ e are up against a contagious self-fulfilling prophecy. That is, an owner, sensing the beginning of a neighborhood's decline, will be loathe to rehabilitate since an isolated renovation in a sea of "encroaching deterioration" will be both futile and financially [disastrous]. This premature pessimism results in an area quickly snowballing from sound to slightly bad to deteriorating and finally to total abandonment. ...

... In a very real sense, abandonment signals a [community's] decline; when bad

buildings are vacated, the other owners begin to panic and good houses in the

vicinity are abandoned at the same time.

Scnate Hearings, supra note 1 , at 807.

This process, also termed a "domino" or "contagion" effect, has been widely recognized. J. Hughes \& K. BleAkLY, supra note 3, at 57-58. See HUD, supra note 1, at 9; Nachbaur, stupra note 2, at 10-11; Comment, supra note 14, at 856-57, 874. But see GricsBy, supra note 1 , at 208 .

20. Many cities require the owner of an abandoned building to have it sealed or continuously guarded. E.g., L.A. MU., Code $\$ 57.20 .12$ (1970); N.Y.C. AdMrn. Code $\$$ C26-80.0 (1969). See Comment, supra note 14 , at 875 (Detroit). Illinois, however, has a statutory policy against sealed buildings. An unsafe or abandoned building must be either repaired by the owner or demolished. ILL. REv. Stat. ch. 24, $\$ 11-31-1$ (Smith-Hurd Supp. 1976). Cities also can demolish buildings which present health or safety hazards and take liens on the property for the cost of demolition. E.g., id. $\$ 11-31-1$; MAss. ANN. Laws ch. 139, $\$ \$ 1$ 1-3A (Michie/Law. Co-op Supp. 1976); N.Y. MULT. Dwel.L. LAw $\$ \$ 309.2,309.4$ (Mckinney 1974). In New York, if a building is a nuisance but does not require demolition, the city may ask the court to place the building in receivership. Id. $\$ 309.5$. See Note, The New York City Housing Receivership and Communily Management Programs, 3 Fordham URB. L.J. 637 (1975).

In addition, cities may acquire title to buildings for whicil property taxes are in 
effective. ${ }^{21}$ Nor can courts be expected to mandate enforcement of anti-abandonment laws. ${ }^{22}$ Neighbors, therefore, must seek other remedies.

arrears. E.g., N.J. STAT. ANN. \$ 54:5-19 (West 1960); N.Y.C. Admin. Code \$ D17-4.0 (Supp. 1975). New York City has a special proceeding to acquire title to multiple dwellings which have been abandoned. N.Y. RE4L Prop. Actions LAw \$\$ 1970-1974 (McKinney Supp. 1975) (title may be taken (a) where building is occupied, if owner has failed to demand rent for three months and his neglect has rendered building dangerous, or (b) where building is vacant and unsealed, if government agency has prohibited occupancy or taxes are in arrears for at least one year). Buildings acquired by cities may be demolished, sold, rehabilitated with public funds, or turned over to homesteaders. See Note, Homesteading 1974: Reclaiming Abandoned Houses on the Urban Fronticr, 10 Colum. J.L. \& Soc. Pros. 416 (1974); Note, Low Income Co-ops: A Solution to Abandonment, 17 N.Y.L.F. 148 (1971); Note, supra note 18, at $735 \mathrm{n} .2$.

21. The sealing statutes have been generally ineffective. Vandals and derelicts simply break through the barricades, so that the building continues to cause substantial harm to the neighborhood. Comment, supra note 14 , at 875 . See Senate Hearings, supra note 1 , at $829,833-34$.

Demolition has been used with some frequency, at least in Newark, see J. Hughes \& K. BlEAKLY, supra note 3, at 218, and Detroit, Comment, supra note 14, at 869 . But even where demolition programs are carried out, a building usually will remain standing, generating negative externalities, for $23 / 2$ to eight months after a complaint is filed. Id. Beyond these problems, there are legal limits to what such programs can accomplish. Under the due process clause of the New York Constitution, a city cannot order demolition unless the abandoned building creates an "imminent peril to the public health" that sealing and securing would fail to eliminate. Ozone Holding Corp. v. City of New York, 79 Misc. 2d 744, 750, 361 N.X.S.2d 558, 565 (Sup. Ct. 1974). Illinois cities may not demolish a building unless the owner is given a reasonable opportunity to repair dangerous conditions. City of Aurora v. Meyer, 38 Ill. 2d 131, 136.37, 230 N.E.2d 200, 203-04 (1967). See City of Chicago v. General Realty Corp., 133 Ill. App. 2d 662, 273 N.E.2d 712 (197I), cert. denied, 406 U.S. 945 (1972). Yet a reparable building or one that is not an "imminent peril" may still inflict serious harm on the community. Moreover, since demolition programs are not directly responsive to the level of externalities generated by a building and since the owner's exposure to loss under the programs is limited to the cost of demolition discounted by the probability of enforcement, the owner has little incentive to prevent externalities. Liability for damage would provide a more substantial incentive. The damages assessed would be directly related to the level of externalities generated by the building.

Receivership is ill-adapted to the problem of abandonment because it is slow and expensive. See Note, Receivership of Problem Buildings in New York City and its Potential for Decent Housing of the Poor, 9 Colun. J.L. \& Soc. Pron. 309, 340-48, 350 (1973). Consequently, it is rarely used. See Note, The New York Cily Housing Receivership and Community Management Programs, supra note 20, at 659 (in 1975, only $10 \mathrm{~s}$ buildings in New York City were in receivership). Cities may not institute foreclosure proceedings unless taxes have been in arrears for at least one year. See, e.g., Mich. CoMr. LAws ANN. \$ 211.60 (Supp. 1976) (three years); N.J. STAT. ANN. \$ 54:5-19 (West 1970) (one year); N.Y.C. ADMIN. Code $\$$ D17-40 (Supp. 1975) (three years). The results of New York City's special streamlined proceeding to acquire titie to abandoned multiple dwellings also have been disappointing because loopholes have limited the applicability of the new proceeding. See N.Y. Times, Feb. 26, 1974, at 42, col. 6 .

The destructive effects of an abandoned building in a transitional area begin to appear almost contemporaneously with the abandonment. See note 19 supra. Programs with substantial lag times are thus of marginal value to residents in such areas.

22. Courts generally will not issue a writ of mandamus to a city agency acting within its discretion. See Perazzo v. Lindsay, 30 App. Div. 2d 179, 290 N.Y.S.2d 971, aff'd, 23 N.Y.2d 764, 244 N.E.2d 471, 296 N.Y.S.2d 957 (1968). Enforcement of anti-abandonment statutes is largely discretionary. In New York City, for cxample, the Housing and 


\section{The Nuisance Approach}

Nuisance law offers a means of dealing with the harmful externalities of abandonment.. ${ }^{23}$ The owner of an abandoned building that is a fire, health, or safety hazard can be held liable for maintaining a public nuisance. ${ }^{24}$ The effects of the abandonment on nearby residents may be sufficiently different in kind from harms suffered by the general public to give these residents a private right of action. ${ }^{25}$ Neighbors who can demonstrate that the building has interfered with the use or enjoyment of their property may also seek relief for a private nuisance. ${ }^{26}$ But regardless of the theory upon which the suit is predicated, the plaintiff must show that the defendant's conduct has been unreasonable. Reasonableness usually is determined by balancing the gravity and probability of the harm imposed on the plaintiff against

Development Administration is responsible for deciding when an abandoned building "is a fire hazard or in a condition dangerous or detrimental to human life, health or morals" and should be demolished. N.Y. MULT. Dwell. LAw $\$ 309.2$. a (McKinney 1974).

23. For general discussions of nuisance law, see W. Prosser, HANDBOOK OF the LAW of ToRTs $\$ \$ 88,89$ (4th ed. 1971); Restatement (SrCoND) of ToRTs $\$ \$ 821 \mathrm{~B}-828$ (Tent. Draft No. 17, 1971) [hereinafter cited as Restatement].

24. City \& County of San Francisco v. Meyer, 208 Cal. App. 2d 125, 25 Cal. Rptr. 99 (1962); City of Chicago v. Birnbaum, 49 Ill. 2d 250, 274 N.E.2d 22 (1971); Beauchamp v. New York City Hous. Auth., 12 N.Y.2d 400, 190 N.E.2d 412, 240 N.Y.S.2d 15 (1963).

An abandoning owner remains responsible for his property since abandonment does not extinguish legal titlc. See Hunter v. Schultz, 240 Cal. App. 2d 24, 28, 49 Cal. Rptr. 315, 317 (1966). Puritan Holding Co. v. Holloschitz, 82 Misc. 2d 905, 372 N.Y.S.2d 500 (Sup. Ct. 1975).

25. Although public nuisance actions usually are brought by cities, private individuals can recover if the damage they suffer is distinguishable from that suffered by the general public. W. Prossrr, supra note 23, $\$ \$ 86,88$, at 572-73, 586. See Prosser, Private Action for Public Nuisance, 52 VA. L. Rev. 998 (1966). For example, neighbors of abandoned buildings may suffer a decline in their property values which constitutes special damages. "There are even cases in which a substantial depreciation in the value of the land, apart from any other interference, has been held to be in itself sufficient particular damage." Id. at 1019-20. See Restatement, supra note 23 , $\$ 821 \mathrm{C}$, comment h (pecuniary loss); Graceland Corp. v. Consolidated Laundries Corp., 7 App. Div. 2d 89, 93, 180 N.Y.S.2d 64, 618 (1958), aff'd, 6 N.Y.2d 900, 160 N.E.2d 926, 190 N.Y.S.2d 708 (1959) (plaintiff suffered special damage because of decline in rental value of his property). But see Biber v. O'Brien, 138 Cal. App. 353, 361, 32 P.2d 425, 429 (1934).

26. Private nuisance is restricted to the "invasion of interests in the use or enjoyment of land," as opposed to public nuisance, which extends to "virtually any form of annoyance or inconvenience interfering with common public rights." W. Prosser, supra note $23, \S 87$, at 572 . Although only one case has so held, Puritan Holding Co. v. Holloschitz, 82 Misc. 2d 905, 372 N.Y.S.2d 500 (Sup. Ct. 1975), an abandoned building probably would interfere with the "use and enjoyment" of nearby property. See Arkansas Release Guidance Found. v. Needler, 252 Ark. 191, 196, 477 S.W.2d 821, 822 (1972) (halfway house enjoined as a private nuisance because convicts it brought to neighborhood caused nearby residents "real and reasonable fear ... . for their safety" and thereby diminished property values); Keenly v. McCarty, 137 Misc. 524, 244 N.Y.S. 63 (Sup. Ct. 1930) (asylum for alcoholics, drug addicts, and insane located in residential neighborhood, restricted to acceptance of non-obtrusive occupants because patients' conduct disturbed neighbors); W. Prosser, supra note 23, $\$ 89$, at 590-93. But see 58 AM. JUR. 2d Nuisances $\S 74$ (1971). 
the social utility of the defendant's conduct..2 Since abandonment has little social utility, a relatively small amount of harm to the neighbors should justify relief. ${ }^{28}$

In some states, neighbors suffering "substantial harm" from a nuisance can obtain an injunction ordering its abatement. ${ }^{20}$ Courts in other states grant an injunction only when defendants' costs of compliance are less than the damages suffered by plaintiffs. ${ }^{30}$ If injunctive relief is granted, damages are awarded only for harm suffered during existence of the nuisance. ${ }^{31}$ If an injunction is denied, neigh826.

27. W. Prosser, supra note $23, \S 87$, at $580-82$; Restatement, supra note 23 , $\$ \$ 822(a)$,

28. Some commentators have suggested that this balancing test be used not to determine whether to award damages, but only to decide whether an injunction is appropriate. Restatement, supra note 23, at 31-32 (proposals by Professors James and Keeton for $\$ 822)$; Ellickson, Alternatives to Zoning: Covenants, Nuisance Rules, and Fines as Land Use Controls, 40 U. CHI. L. Rev. 681, $720-21$ (1973).

29. E.g., Boomer v. Atlantic Cement Co., 26 N.Y.2d 219, 223, 257 N.E.2d 870, 872, 309 N.Y.S.2d 312, 315 (1970); Theatre Estates, Inc. v. Village, 462 P.2d 651, 653 (Okla. 1970); 5 R. Powell, Law of Real Property If 707, at 341.3-.4 (1975).

Demolition of an abandoned building is the most effective and equitable means of abating the nuisance. Sealing the building, a requirement in some cities, does not reduce significantly the harmful effects of abandonment. See note 21 supra. Ordering an owner to continue in operation at a loss might be characterized as a taking without just compensation and therefore a violation of the due process clause of the Fourteenth Amend. ment.

Although demolition substantially reduces harmful externalities, it does not extinguish the owner's responsibility for the property. The remaining vacant lot could become a dumping ground for garbage and, consequently, a health hazard and nuisance to nearby residents. See Dexter v. Bebenek, $458 \mathrm{~Pa}$. 1, 327 A.2d 38 (1974). The additional burden on the owner-to police the property even after demolition-seems somewhat unfair, since he probably cannot sell the land. Nevertheless, nearby residents have a right to protection from such interference with the use and enjoyment of their property. One solution would be to allow an owner forced to demolish his building to quitclaim his lot to the local government, which would police it as part of its general sanitation operations. The minimal cost involved thus would be spread among all taxpayers.

30. It has been proposed that the balancing test be cast in broader terms-weighing the social costs of compliance against the harm alleviated. See Ellickson, supra note 28, at 720. This test mandates consideration of such costs as the loss of jobs if a polluting factory is closed. See Boomer v. Atlantic Cement Co., 26 N.Y.2d 219, 257 N.E.2d 870 , 309 N.Y.S.2d 312 (1970). However, since demolition of an abandoned building should involve insignificant social costs, only the defendant's costs of compliance need be weighed in the balance.

The states are almost equally divided between those that use a balancing test and those that do not. $5 \mathrm{R}$. Powell, supra note 29 , II 707, at 344.3-.4. Commentators have favored the balancing test as a means of preventing cconomic waste. $I d$. at 344.5 . Sec Ellickson, supra note 28 , at 720 .

31. E.g., Spaulding v. Cameron, 38 Cal. 2d 265, 270, 239 P.2d 625, 629 (1952); Shearing v. City of Rochester, 51 Misc. 2d 436, 440-41, 273 N.Y.S.2d 464, 468-69 (Súp. Ct. 1966).

Cognizable harms suffered during existence of the nuisance include the reduced rental value of nearby property as well as any resulting annoyance or physical discomfort to residents. See, e.g., Acadia, Cal., Ltd. v. Herbert, 54 Cal. 2d. 328, 337, 353 P.2d 294, 299, 5 Cal. Rptr. 686, 691 (1960) (damages for discomfort and suffering); Krulikowski v, Poly. cost Corp., 153 Conn. 661, 670, 220 A.2d 444, 449 (1966); Mandell v. Pasquaretto, 76 Misc. 2d 405, 410, 350 N.Y.S.2d 561, 567 (Sup. Ct. 1973); 58 AM. Jur. $2 d$ Nuisances $\$ \$ \$ 122$, $124(1971)$. 
bors can recover for the permanent injury to their property, ${ }^{32}$ measured by the decline in its market value. ${ }^{33}$ Plaintiffs who do not seek an injunction are limited to damages for retrospective harm if the nuisance can be abated. ${ }^{3 t}$ Where the nuisance cannot be eliminated, permanent damages are appropriate. ${ }^{35}$

More extensive use of nuisance laww ${ }^{36}$ would provide neighbors with protection not dependent on local government initiative. But presently, the substantial harm requirement and the balancing tests often may prevent plaintiffs from obtaining relief until an abandoned building is generating substantial externalities. ${ }^{3 \pi}$ Moreover, many such buildings are not currently considered nuisances. ${ }^{38}$

Accordingly, to facilitate and encourage resort to the nuisance remedy, courts should treat abandoned buildings as nuisances per se. Proof of abandonment ${ }^{39}$ would leave only the question of remedy to

32. See Boomer v. Atlantic Cement Co., 26 N.Y.2d 219, 226-27, 257 N.E.2d 870, 874, 309 N.Y.S.2d 312, 318 (1970); 5 R. Powell, supra note 29, fi 706, at 338 \& n.22.

33. 5 R. Powel., supra note 29, 7707 , at 344.9; e.g., Kinley v. Atlantic Cement Co., 42 App. Div. 2d 496, 498, 349 N.Y.S.2d 199, 201 (1973).

34. See, e.g., Kornoff v. Kingsburg Cotton Oil Co., 45 Cal. 2d 265, 268-69, 288 P.2d 507, 509 (1955); Spaulding v. Cameron, 38 Cal. 2d 265, 267-70, 239 P.2d 625, 627-29 (1952); Miller v. Town of Ankeny, 253 Iowa 1055, 1062, 114 N.w.2d 910, 914 (1962); Pettingill v. Turo, 159 Me. 350, 357, 193 A.2d 367, 372 (1963). But see Puritan Holding Co. v. Holloschitz, 82 Misc. 2d 905, 372 N.Y.S.2d 500 (Sup. Ct. 1975) (court awarded permanent damages without considering whether nuisance could be abated).

35. Sce, e.g., Kornoff v. Kingsburg Cotton Oil Co., 45 Cal. 2d 265, 268-69, 288 P.2d 507, 509 (1955); Boomer v. Atlantic Cement Co., 26 N.Y.2d 219, 226, 257 N.E.2d 870, 874, 309 N.Y.S.2d $312,318(1970)$.

36. See note 4 supra.

37. These threshold requirements frustrate efforts to remove abandoned buildings before expectations about the neighborhood's future decline. Also, the threshold requirements add to the evidentiary burden on the plaintiffs, increasing their costs of litigation and thus deterring nuisance suits.

38. Even if an abandoned building is not a health, fire, or safety hazard, it still may inflict aesthetic injuries on the community. See note 18 supra. Courts have been reluctant to predicate nuisance liability on such harms. See, e.g., People v. Oliver, $86 \mathrm{Cal}$. App. 2d 885, 887-88, 195 P.2d 926, 928 (1948); Mahlstadt v. City of Indianola, 251 Iowa 222, 232, 100 N.W.2d 189, 195 (1959); Cahill v. Heckel, 87 N.J. Super. 201, 204, 208 A.2d 651, 652 (1965). But see University Gardens Property Owners' Ass'n v. University Gardens Corp., 21 Misc. 2d 243, 189 N.Y.S.2d 998 (Sup. Ct. 1959), aff'd, 10 App. Div. 2d 993, 203 N.Y.S.2d 250 (1960); Brown v. Arbuckle, 88 Cal. App. 2d 258, 263, 198 P.2d 550, 553 (1948) (funeral homes in residential areas held private nuisances because they create constant awareness of death). Nor will courts impose nuisance liability for an activity simply because it depresses property values. See, e.g., Taliaferro v. Salycr, 162 Cal. App. 2d 685, 691, 328 P.2d 799, 802 (1958); Township of Garfield v: Young, 348 Mich. 337, $343.44,82$ N.W.2d 876, 879 (1957). Aesthetic costs which depress property values are as tangible as costs imposed by other kinds of nuisances. They should therefore be compensable. Ellickson, supra note 28, at 734-35. Sec Nocl, Unaesthetic Sights as Nuisances, 25 Corvel. L.Q. 1 (1939); Note, Aesthetic Nuisance: An Emerging Cause of Action, 45 N.Y.U. L. REv. 1075 (1970).

39. A building should be considered abandoned once it has been vacant for a period determined by the courts or legislature. Where a few tenants remain in a building nearly vacant, it should be presumed abandoned. An owner may rebut that presumption 
be litigated. In transitional areas, ${ }^{40}$ the externalities of abandonment should be presumed to outweigh the costs of demolition. Such a presumption would alleviate the evidentiary burden on the neighbors and would allow them to obtain injunctive relief before the building caused substantial harm. ${ }^{41}$ In other areas, damages from abandonment would be less severe, depriving neighbors of the benefit of the presumption. Injunctive relief thus would be less readily available; the plaintiffs would have to prove their damages. However, once the per se rule resolved the issue of liability, the parties would have an incentive to settle in order to avoid incurring substantial litigation costs. In either transitional or deteriorated neighborhoods, the per se rule would bring all abandoned buildings generating externalities within the reach of nuisance law.

\section{Limitations of the Nuisance Approach}

Three factors may limit the effectiveness of the nuisance approach. First, many abandoning owners cannot be forced to satisfy nuisance judgments. Second, where judgments are enforceable, damages may be difficult to measure. Finally, the costs of litigation may outweigh the benefits of reducing the externalities of abandonment.

The nuisance remedy will be a hollow one if owners cannot be compelled to satisfy judgments. Little is known about the characteristics of abandoning owners; many of them may be judgment-proof. However, it is reasonable to assume that a substantial number of in-

by showing that he has continued to collect rent, provide essential services, and seek additional tenants. For other definitions of abandonment, see N.Y. REAL Prop. Actions LAw \$ 1971 (McKinney Supp. 1975); J. Hughrs \& K. BLEAKLY, supra note 3, at 213-36. See also STERnLIEB, supra note 1, at 274-79.

40. In defining a transitional area, the court could employ statutory criteria used in urban rehabilitation programs. See note 3 supra. But to forestall extended litigation over whether a neighborhood is transitional, courts should accept as conclusive any legislative delineations of such areas.

41. In transitional areas, the harm caused by abandonment is likely to be far-reaching and significant. See notes $2 \& 19$ supra. In Puritan Holding Co. r. Holloschitz, 82 Misc. $2 d 905,372$ N.Y.S.2d 500 (Sup. Ct. 1975), for example, the owner of an apartment building across the street from an abandoned building recovered $\$ 30,000$ for the decline in the value of his property caused by the abandonment. By comparison, the costs of demolition are not high. In 1972, to level a two-story, wooden frame building in Newark cost between $\$ 1,000$ and $\$ 2,000$. Sternlieb, supra note 1 , at 231 . Demolition of a brick structure is more expensive. See City of Chicago v. General Realty Corp., 133 Ill. App. 2d 662, 666, 273 N.E.2d 712, 715 (1971), cert. denied, 406 U.S. 945 (1972) (cost of demolish. ing three-story brick building containing 23 apartment units and five stores was $\$ 7,963$ ). If tenants continue to live in the building after the owner has abandoned, he must evict them before he can demolish the building. Eviction also may involve legal and social costs. See Robinson v. Diamond Hous. Corp., 463 F.2d 853, 857 (D.C. Cir. 1972) (landlord's efforts to take building off rental market frustrated for over three years by non-rent-paying tenant). 
dividuals owning abandoned buildings have resources sufficient to cover nuisance judgments. ${ }^{42}$ Even when owners are judgment-proof, courts may grant liens on the abandoned property to satisfy some portion of the judgment. ${ }^{43}$

There are further difficulties in recovering judgments if abandoned buildings are owned by close corporations with few assets. ${ }^{44}$ Stockholders of these corporations generally are shielded from tort liability. ${ }^{4} \overline{ }$ As successful nuisance actions are brought, more owners may take refuge behind the corporate form. Yet courts do have equitable power to "pierce the corporate veil" in order to hold stockholders personally liable for the actions of their corporation. ${ }^{46}$ There are strong argu-

42. Sternlieb's study of Newark is the only in-depth inquiry into the characteristics of abandoning owners. A sample of 567 buildings initially surveyed in 1964 was reexamined in 1972 in order to identify the factors causing abandonment. STERNLIEB, supra note I, at xiv. Of owners who had abandoned by 1972, 20.3\% had annual incomes in 1964 exceeding $\$ 20,000 ; 30.5 \%$ earned between $\$ 8,000$ and $\$ 20,000$ a year. $I d$. at 312 . In addition, $74.6 \%$ owned other property, $i d$. at 305 , which probably could be applied toward satisfaction of a damage judgment. On the other hand, $23.8 \%$ earned between $\$ 3,000$ and $\$ 5,000$, and $11.9 \%$ earned less than $\$ 3,000$ a year. $1 d$. at 312 . Since Sternlieb's study focused primarily on slums, his figures may be low in comparison to those for transitional areas. Further, his figures apply only to Newark, and Sternlieb concedes they may not be trustworthy. Id. But if the costs of demolition range from $\$ 1,000$ to $\$ 10,000$, sec note 41 supra, Sternlieb's figures would suggest that a substantial percentage of owners could comply with an injunction, the primary objective in a nuisance action.

Owners with ample resources to satisfy judgments may attempt to escape liability by transferring title to a judgment-proof individual. For example, to avoid fines for building code violations, owners in New York have reportedly transferred title to vagrants in the Bowery, paying them a fee for their services. House Papers, supra note 1, at 325. Such tactics, however, may not enable an owner to evade responsibility for an abandoned building, because liability for a nuisance is not discharged by transfer of title. See N.Y. REAL Prop. ACTIONS LAw $\$ 841$ (McKinney 1963) ("person by whom the nuisance has been erected and a person to whom the property has been transferred may be joined as defendants" in nuisance action); State v. Ole Olsen, Ltd., 38 App. Div. 2d 967, 968, 331 N.Y.S.2d 761, 763 (1972), modified, 35 N.Y.2d 979, 324 N.E.2d 886, 365 N.Y.S.2d 528 (1975). See also O'Connor v. Altus, 123 N.J. Super. 379, 384-85, 303 A.2d 329, 331 (1973), modified, 67 N.J. 106, 335 A.2d 545 (1975). But see Maisenbach v. Buckner, 133 Ill. App. 2d 53, 272 N.E.2d 851 (1971).

43. Cities take similar liens under demolition and receivership programs. See note 20 supra. However, abandoned property generally will not be very valuable. Exceptions may be found in transitional areas or in cases in which the abandoning owner for some reason was unable to realize the economic potential of his property. Cf. note 12 supra.

44. See Note, Should Shareholders Be Personally Liable for the Torts of Their Corporations? 76 YALE L.J. 1190, 1191-92 \& n.10 (1967). For general statistics on ownership of slum housing, see Gricsby, supra note 1, at 161; STERnLIEB, supra note 1, at 56; Ackerman, Regulating Slum Housing Markets on Behalf of the Poor: Of Housing Codes, Housing Subsidies, and Income Redistribution Policy, 80 YALE L.J. 1093, 1099 n.7 (1971).

45. The law permits incorporation of a business for the very purpose of enabling its owners to escape personal liability. E.g., Walkovszky v. Carlton, 18 N.Y.2d 414, 417, 223 N.E.2d 6, 7, 276 N.Y.S.2d 585, 587 (1966); Elenkrieg v. Siebrecht, 238 N.Y. 254, 262, 144 N.E. 519, 521 (1924); H. HeNN, LAw of CoRporations $\$ 146$ (2d ed. 1970).

46. Courts agree that they have the power to picrce the corporate veil to achieve equity, but they vary in their willingness to invoke this power. Compare Bangor Punta Operations, Inc. v. Bangor \&. A.R.R., 417 U.S. 703, 713 (1974) and Swanson v. Levy, 509 F.2d 859, 861-62 (9th Cir. 1975) with Zubik v. Zubik, 384 F.2d 267, 273 (3d Cir. 1967), 
ments for using this power to reach owners of abandoned buildings. Arguably, the liability was foreseeable; the corporation should have maintained adequate capital to satisfy adverse judgments. ${ }^{47}$ Moreover, disregarding the corporate structure would promote a public policy of recognized importance ${ }^{t 8}-$ the preservation of the urban environment. ${ }^{49}$ If courts choose not to rely on equitable doctrine, they still may ignore the corporate structure if there has not been strict compliance with corporate formalities. ${ }^{50}$

Governmental agencies may also own abandoned buildings. The Federal Housing Authority (FHA) may take title to abandoned build. ings when owners default on mortgage payments. ${ }^{\jmath 1}$ City governments may take title when property taxes are in arrears. ${ }^{52}$ The city or the FHA thereby assumes responsibility to abate the nuisance; either may

cert. denied, 390 U.S. 988 (1968) -and Walkovszky v. Carlton, 18 N.Y.2d 414, 223 N.E.2d 6, 276 N.Y.S.2d 585 (1966). See H. HENN, supra note 45, $\$ \$ 146-147$. There is, however, a growing tendency for courts to disregard the corporate fiction. 1 W. FLETCHER, CYcLopenIA of the Law ofePrivate Corporations $\$ 41$, at 166 (1974); F. O’Neal, Close Corporitions $\S 1.09 \mathrm{a}$, at $34(1971)$.

47. Where a corporation has neither adequate capital nor insurance to provide for risks of loss foreseeable in its line of business, the corporate form often is disregarded. See Mull v. Colt Co., 31 F.R.D. 154 (S.D.N.Y. 1962); Minton v. Cavaney, 56 Cal. 2d 576, 364 P.2d 473, 15 Cal. Rptr. 641 (1961) (dictum). But see Walkovszky v. Carlton, 18 N.Y.2d 414, 223 N.E.2d 6, 276 N.Y.S.2d 585 (1966).

48. See Bangor Punta Operations, Inc. v. Bangor \&. A.R.R., 417 U.S. 703, 713 (1974) ("corporate form may be disregarded in the interests of justice where it is used to defeat an overriding public policy"); see, e.g., Capital Tel. Co. v. FCC, 498 F.2d 734, 737 (D.C. Cir. 1974) (corporate veil pierced to promote fair and efficient distribution of radio service).

49. In 1973, the New York legislature concluded that the abandonment problem was a "public emergency," and found that abandoned buildings "are hazardous to human life, health, safety and morals, have a deleterious effect on the community as a living environment, and attract vandals and other criminals." N.Y. REAL Prop. Actions LAw $\$ 1970$ (McKinney Supp. 1975) (legislative findings). Accordingly, the legislature has denied the protection of the corporate form to major stockholders of corporations owning multiple dwellings that are declared nuisances. N.Y. MULT. DWELL. LAW \$ 304.8 (McKinney 1974). See also Kurtigian v. City of Worcester, 348 Mass. 284, 291, 203 N.E.2d 692, 696 (1965) (city held liable for private nuisance; public policy required that someone be responsible for nuisances on urban property).

50. Courts have disregarded the corporate form where there is such a unity of interest and ownership that the separate personalities of the corporation and the individual no longer exist. See, e.g., Segan Constr. Corp. v. Nor-West Builders, Inc., 274 F. Supp. 691, 698-99 (D. Conn. 1967); 1 W. Fletcher, supra note 46, $\$ 41.1$, at 171. The factors examined include whether stock was issted, whether other legal formalities were followed, and whether corporate and personal finances were segregated. Von Brimer $\mathbf{v}$. Whirlpool Corp., 362 F. Supp. 1182, 1194 (N.D. Cal. 1973).

51. The Department of Housing and Urban Development through the FHA has become the unwilling owner of about 100,000 abandoned housing units. N.Y. Times, Dec. 11, 1975, at 1, col. 7. For a description of the deficiencies of the HUD mortgage guarantee programs that lead to FHA acquisitions, see Comment, supra note 14, at 858-59.

52. In 1972, New York City held 2,000 abandoned residential buildings obtained through tax foreclosure. N.Y. Times, May 2, 1972, at 18, col. 4. 
be liable for damages if it neglects to do so. ${ }^{53}$ Although recovery of those damages in some jurisdictions might be barred by the defense of sovereign immunity, most states do permit nuisance actions against cities, ${ }^{54}$ and claims against the FHA might be permitted under the Federal Tort Claims Act. .5 $^{5 .}$

A second problem with the nuisance approach involves proof and measurement of damages to property..$^{56}$ If an injunction were granted, damages would be awarded for the reduced rental value of neighbors' property during the existence of the nuisance and for any physical injuries sustained, such as fire loss. ${ }^{57}$ Damages for physical injuries should be easily ascertainable, and any reduction in rental value would be reflected in the lower rental rates actually charged. ${ }^{58}$ If the neighbors did not obtain injunctive relief, damages would be awarded for the permanent depreciation in the market value of their property.59

53. A transferee of real property upon which there exists a nuisance created by his predecessors in title is liable if he knowingly maintains the nuisance or permits its continuation. 58 AM. JUR. 2d Nuisances $\$ 51$ (1971). Some states have abolished the scienter requirement by statute, holding the transferee liable on the same basis as the creator of the nuisance. See, e.g., N.Y. Real Prop. Actions Law \$ 841 (Mckinney 1963). $A$ scienter requirement is not a significant limitation in the case of a transfer of an abandoned building, because the nature of the nuisance should be apparent to the transferee.

54. Although some jurisdictions have declined to hold city agencies liable in tort for actions performed in a "governmental" capacity, e.g., Wickman v. Housing Auth., 196 Ore. 100,247 P.2d 630 (1952), the "overwhelming weight of authority [indicates that] local governments creating or maintaining nuisances are liable in tort, regardless of whether the activity resulting in harm is characterized as 'proprietary' or 'governmental." "1A C. Antieav, Municipai. Corporation Law \$ 11.08, at 11-18 (1974). See, e.g., Kurtigian v. City of Worcester, 348 Mass. 284, 287-88, 203 N.E.2d 692, 694 (1965).

55. 28 U.S.C. $\$ 1346(\mathrm{~b})(1970)$. See also Note, supra note 12 , at 586 (suggesting that where government land planning decisions negligently create nuisances, suits under Federal Tort Claims Act should be allowed).

56. A related problem, susceptible to traditional tort law analysis, is the apportionment of damages among a number of abandoning owners. To illustrate, $B$ abandons his building, claiming that he would not have done so but for the harmful external effects generated by his neighbor $A$ 's abandonment one month earlier. $C$ suffers a decline in the value of his property and sues both $A$ and $B$ for maintaining nuisances. $A$ would be liable for $B$ 's loss. His liability probably would be measured by the present value of the rental income of $B$ 's property over its expected lifetime. If $B$ were on the verge of abandonment before $A$ abandoned, then that expected lifetime would be rather short and damages insubstantial. $A$ and $B$ would be liable for their proportionate shares of damages due $C$. If damages suffered by $C$ cannot be divided between the two tortfeasors, both will be jointly and severally liable for the entirc amount. See, e.g., Schindler v. Standard Oil Co., 166 Ohio 391, 394, 143 N.E.2d 133, 136 (1957); W. Prosser, supra note $23, \S 52$.

57. See note 31 supra.

58. A more difficult evidentiary problem would arise if neighbors suffered damages in the form of foregone rent increases. But an abandonment in the neighborhood would normally suggest that rents there were not increasing. See also note 7 supra.

59. See pp. 1136-37 \& notes 32-33 supra. Even if the neighbor cannot sustain the burden of proving that the abancloned building has adversely affected property values, he still is entitled to damages for personal annoyance and discomfort. See note 31 supra. 
In areas characterized by decreasing property values, it may be difficult to segregate that part of the decline in value due to the abandoned building. Yet courts and juries often must assign values where no clear market standard is available-for example, in assessing damages for pain and suffering. Thus, although the damage questions are difficult, they are not uniquely so.

A third objection to encouraging nuisance actions is the high cost of resolving disputes in the courts. Where the damage caused by an abandoned building is slight, the costs of a nuisance action to the parties and to the court system may outweigh the benefits accruing to the neighbors as a result of the elimination of externalities. ${ }^{60}$ Legal expenses, however, are likely to deter many plaintiffs from bringing actions where damages are inconsequential. ${ }^{61}$ Moreover, the overall social costs of nuisance litigation may be exaggerated. The per se rule should simplify the issues at trial. ${ }^{62}$ In addition, once the question of injunctive relief has been resolved, the amount of damages at stake often may not merit the costs of further litigation. The parties thus would have an incentive to settle. Legal expenses also are likely to induce neighbors to consolidate their claims into a single action, resulting in a substantial savings in total litigation costs. ${ }^{63}$ To reduce costs further, jurisdiction over nuisance actions could be vested in courts adapted or created to hear them. ${ }^{64}$

60. See Ellickson, supra note 28 , at 737 .

61. Put simply, a rational neighbor would pursue a claim if the expected costs of litigation were Iess than his expected benefits discounted by the perceived probability of success. The neighbor, however, would not consider the costs his suit imposes upon the abandoning owner or on the judicial system. Id. It thus is possible that suits might be brought seeking damages less than the total cost of adjudicating the claim. On the other hand, the neighbor also may not consider benefits accruing to society from the reduction of the harmful effects of abandonment. Benefits such as the reduced burden on fire departments and the increased safety of people using the streets may offset the excess costs.

62. See pp. 1137-38 supra.

63. Rules of joinder should permit such consolidation. See, e.g., FED. R. Civ. P. 20; Cal. Civ. Proc. Code $§ 378$ (West 1973); N.Y. Civ. Prac. LAw $\S 1002$ (McKinney 1963). A nuisance suit also may be brought by a neighborhood association in the name of its members. See, e.g., Fed. R. Civ. P. 23.2; Cal. Civ. Proc. Code $\S 388$ (West 1973); N.Y. GEN. Ass'ns Law $\$ 12$ (McKinney 1942). For an account of an active neighborhood association attempting to combat the harmful effects of abandoned buildings, see New Haven Advocate, Feb. 25, 1976, at 2, col. 1 (on file with Yale Law Journal). Courts have been reluctant to allow nuisance suits to be brought as class actions because of differences among class members in property owned and damages suffered. City of San Jose v. Superior Court, 12 Cal. $3 d$ 447, 460-65, 525 P.2d 701, 710-13, 115 Cal. Rptr. 797, 806-09 (1974); Nowack v. Department of Audit \& Control, 72 Misc. 2d 518, 519, 338 N.Y.S.2d 52, 53-54 (Sup. Ct. 1973). But see Foster v. City of Detroit, 405 F.2d 138, 146 (6th Cir. 1968) (common questions of law and fact override differences in damages suffered by each individual plaintiff).

64. One commentator has suggested that "nuisance boards" be established to handle nuisance litigation. Such boards would be authorized to award injunctions and damages. 


\section{Economic Implications of the Nuisance Approach}

\section{A. Efficiency Considerations}

Imposition of liability on the abandoning owner would promote efficiency in the housing market. ${ }^{65}$ Presently, the owner of a building can abandon "for free"; he assumes no liability for the costs that the abandonment imposes on others. Therefore, the profit-maximizing owner weighs only his own costs and benefits in deciding whether to abandon, rather than also considering the resource cost to society. $\mathrm{He}$ does not undertake measures to mitigate the harmful externalities of the abandoned building to the point where further mitigation entails more social costs than social benefits. The nuisance approach would force the abandoning owner to bear these external costs of his actions, thereby leading to a reduction in the rate of abandonment and in its harmful effects. ${ }^{60}$

They also could appoint special officers to investigate situations and recommend appropriate relief. Ellickson, supra note 28, at 762-66. In New York, nuisance actions could be handled by the city's Housing Part, a court specializing in housing code violations. See Rutzick \& Huffman, The New York City Housing Court: Trial and Error in Housing Code Enforcement, 50 N.Y.U. L. REv. 738, $749-52$ (1975); Note, The New York City Housing Part: New Remedy for an Old Dilemma, 3 FordhaM URB. L.J. 267 (1975).

65. A policy promotes efficiency if it reduces the social costs of achieving a given quality and quantity of housing. Cf. Ellickson, supra note 28, at 688 ("A measure is inefficient if it is likely to waste resources ....")

66. Another method of accomplishing this goal is to fine the owner of an abandoned building that is inflicting substantial harm on the neighborhood. The owner would spend a sum up to the amount of the fine to reduce externalities. However, the nuisance approach has three advantages over a system of fines. First, it is probable that a system of fines, like other anti-abandonment programs, would not be aggressively enforced. See note 21 supra. Unless the fine imposed were very large, random enforcement would be an inconsequential deterrent to the abandoning owners. Second, fines would not compensate injured neighbors for their losses. As long as neighbors continued to bear the risk of loss from abandonment, they would be deterred from maintaining or rehabilitating their propertics. Third, reduction of externalities under a system of uniform fines would bear no relationship to the harm suffered by the neighbors, but would depend simply on the relation between the cost of demolition and the size of the finc. Assume the fine were set at $\$ 6,000$ and the cost of demolition were $\$ 5,000$. An abandoning owner who would cause only $\$ 2,000$ damage would demolish the building to avoid paying the fine. As a result, the costs of reducing the externalitics would exceed the benefits to neighbors from the reduction. Under the nuisance approach, an injunction ordering demolition would not be granted in this situation. Rather, permanent damages of $\$ 2,000$ would be awarded. See pp. 1136-37 supra. Of course, if the fine were always set below the cost of demolition, "inefficient" demolition would not occur. But the abandoning owner then would have no incentive to demolish his building even in situations where it would be desirable. He would choose instead to pay the fine. Neighbors thus would not be protected from abandonment unless the city itself demolished the building-in effect, subsidizing the owner by an amount equal to the difference between the cost of demolition and the fine. 
In a world where transaction $\operatorname{costs}^{67}$ are zero, net social benefits ${ }^{6 s}$ would be maximized regardless of who bore the burden of reducing externalities. If the abandoning owner were not liable for these external effects, the neighbors would band together and pay him to reduce externalities until the costs of reducing them further outweighed the incremental benefit to the neighbors. In this "frictionless" world either placing liability on the owner or allowing the costs to fall on the neighbors would produce an efficient outcome. ${ }^{60}$

But there are, in fact, significant transaction costs. Therefore, to

67. Transaction costs have been defined as those costs "which inhibit competitive markets from working." Polinsky, Economic Analysis as a Polentially Defectiv'e Product: A Buyer's Guide to Posner's Economic Analysis of Law, 87 HARv. L. REv. 1655, 1667 (1974). Implicit in the notion of zero transaction costs are the assumptions that the parties to the bargain have perfect information and that they can cnter into an agreement without cost. Id.

68. The social cost of abandonment may consist of more than harm to the immediate neighbors. See note 61 supra. For any isolated abandonment, however, it is reasonable to assume that these additional social costs would be insubstantial.

69. See Coase, The Problem of Social Cost, 3 J. Law \& Econ. 1, 8 (1960). Sec also Calabresi, Transaction Costs, Resource Allocation, and Liability Rules-A Comment, 11 J. LAw \& EcoN. 67 (1968); Demsetz, When Does the Rule of Liability Matler?, I J. LEG.AL STUD. 13 (1972). The dynamics of the situation where the neighbors have a legal remedy against the owner also can be simply described. If the costs of eliminating the harmful effects of an abandoned building are less than the losses suffered by the neighbors, the owner will reduce the externalities himself rather than pay damages to the neighbors. On the other hand, where the costs of eliminating the harmful external effects exceed the losses suffered by the neighborhood, externalities would not be reduced. The owner, if liable for damages, would pay the neighbors rather than spend more money to correct the condition of the building.

If each neighbor's sensitivity to the external effects of abandonment varied with changes in his income level, the actual quantity of externalities reduced through bargaining would depend on whether the abandoning owner were liable for damages. Sce Calabresi \& Melamed, Property Rules, Liability Rules, and Inalienability: One Tiew of the Cathedral, 85 HaRv. L. Rev. 1089, 1095-96 \& n.14 (1972).

It is necessary at this point, as it is in every discussion of economic efficiency, to acknowledge the challenge posed by the "theory of the second best." See F. SchERER, Industrial Market Structure and Economic Performance 22-27 (1970); D. Winch, Analytical Welfare Economics 110-16 (1971); see also R. Posner, Economic Analysis OF THE LAw 112-13 (1972) (simple exposition of a second-best problem). By placing nuisance liability on the abandoning owner, one is trying to force the "price" of abandonment to reflect fully the costs of that activity-a necessary condition for optimal resource allocation. But if the conditions for optimal resource allocation are not fulfilled in all markets in the economy, the theory of the second best states that a movement to what would be optimal conditions in one market, if resources were allocated optimally throughout the economy, may not, in fact, promote economic efficiency in the economy at large. This Note will not attempt an analytic articulation of the theory of the second best. Suffice it to say that the principal concern is that movements toward "more efficient" conditions in one market may have ramifications in other markets which carry price and output in those markets farther away from conditions necessary for optimal resource allocation in the economy.

But as analyses in other contexts have noted, it is conventionally assumed that these second-order effects are minor when changes in small sectors of the economy are in- 
achieve an efticient outcome, liability should be placed on the abandoning owner if he can (1) most easily initiate a bargain and (2) most cheaply reduce the negative externalities. ${ }^{70}$ Both conditions appear to be satisfied. The abandoning owner can most easily initiate the bargaining process because he generally faces lower transaction costs than his neighbors. Although he must identify and contact the neighbors likely to be injured, he does not confront the problems of internal organization that his neighbors must overcome. These problems include the difficulty of organizing a group of people and reaching a consensus on bargaining positions. ${ }^{71}$ Moreover, the neighbors' efforts may be undermined by freeloader problems-some individual neighbors may decline to participate in the bargaining process because they will share in the benefits of the agreement regardless of participation. ${ }^{{ }^{2}}$

The owner can also most cheaply reduce the negative externalities of the abandoned building. He controls the property where the most efficient methods of reducing externalities can be employed. ${ }^{73} \mathrm{He}$ also enjoys certain informational advantages over his neighbors. For example, his greater familiarity with the building should give him a better idea of which method would be most effective. Further, the neighbors' high organization costs may impede their ability to take any action. ${ }^{74}$

The nuisance approach thus can eliminate the uncompensated diminution of nearby property values and reduce the externalities of abandonment. That reduction, in. turn, should decrease the risk of rapid deterioration in transitional neighborhoods. ${ }^{\top 5}$ Since an owner's decision to repair or upgrade his building depends on the prospects

volved. Sce, e.g., Ackerman, supra note 44, at 1110-11 n.22; see also G. CaLAbresi, The Costs of Accidents: A Leg.AL and Economic Axilysis 87 (1971) (where no "great reordering of the economy is likely as a result . . ., as lawyers or even as political economists, we can fairly safely assume that such an allocation is beneficial").

70. Professor Calabresi has suggested two criteria for determining who should bear the costs of external effects in a world with transaction costs: (1) whoever can most cheaply reduce the costs of these externalities, and (2) where the identity of this individual is uncertain, whoever faces the lowest transaction costs. Calabresi \& Melamed, supra note 69 , at 1096-97. Certainly liability should be placed on a party who meets both these criteria.

71. See Ellickson, supra note 28 , at 725 (suggesting that liability be placed on class of parties likely to have lowest organization costs-usually class with fewest members).

72. See Calabresi \& Mrelamed, supra note 69 , at 1095 \& $n .13$.

73. There are only three means available to forestall the externalities of abandonment, all of which must be employed on the premises of the abandoning owner. The building might be sealed, or demolished. See notes 20 \& 21 supra. Alternatively, the owner might continue to operate the building.

74. For example, they may have difficulty reaching agreement on the apportionment of the costs of any action.

75. See notes 2 \& 19 supra. 
for the neighborhood, ${ }^{76}$ the lower risk should encourage investment in renovation. ${ }^{77}$

Reduced uncertainty about future conditions would also induce financial institutions to invest more capital, on more liberal terms, in urban housing. Investment would be more attractive in housing markets sufficiently stable to permit long-term predictions about the viability of neighborhoods. ${ }^{78}$ An abandoned building may undermine the stability of a neighborhood and depreciate property values throughout the area, compromising even viable investments. ${ }^{70}$ The nuisance approach would counteract this effect. By reducing the externalities of abandonment and improving owner confidence, it would enhance neighborhood stability. Where an abandoned building did threaten the value of a mortgaged property, nuisance law would provide means for a lender to protect its investment. ${ }^{80}$

\section{B. Distributional Considerations}

Frequent resort to the nuisance remedy will bring about a redistribution of resources from abandoning owners to their neighbors. ${ }^{81}$ This

76. Sternlieb, supra note 1 , at 64-65.

77. See note 19 supra.

78. See HUD, supra note 1, at 52-53; Duncan, Hood, \& Neet, Redlining Practices, Racial Resegregation, and Urban Decay: Neighborhood Housing Services as a I'iable Alternative, 7 URBAN LAw. 510, 511, 514 (1975); see also Berger, Goldston, \& Rothrauff Slum Area Rehabilitation by Private Enterprise, 69 CoLuM. L. REv. 739, 750-51 (1969); Project, supra note 9, at 1198-1200. When financial institutions do invest, they may demand a substantial risk premium in the form of hefty finance charges, high interest rates, or short repayment schedules. See Senate Hearings, supra note 1 , at 830 .

Financial institutions do invest in lower income, inner city areas perceived to be stable. Sternlieb found that in Newark's Ironbound, an ethnic, lower class, inner city neighborhood, a local savings and loan association had great success with conventional mortgages. The market for housing in Ironbound was vigorous enough to ensure both "maintenance of value and regular repairs." STERnLIEB, supra note 1, at 246. See W. Nash, Residential Rehabilitation: Private Profits and Public Purposes 158-59 (1959) (Chicago lending institutions cooperated in a program to rehabilitate 75-year-old houses because area residents had a "determined neighborhood spirit").

79. See notes 2 \& 19 supra.

80. Potential liability for harms caused by an abandoned building to which they have taken title might deter financial institutions from investing in urban housing. See generally N.Y. Times, Sept. 11, 1975, at 45, col. 1 (decision holding abandoning owner liable may discourage responsible people from owning real estate). An institution, however, may protect itself by lending to financially responsible owners and by requiring that the owner agree to reimburse the institution for any damages for which it is held liable. If it becomes evident that the nuisance approach is an impediment to investment in urban housing, the legislature could temporarily exempt mortgage lenders from nuisance liability. See, e.g., N.Y. MuLT. Dwell. LAw \$304.6 (McKinney 1974) (exempting financial institutions from any civil or criminal liability for maintenance of building as public nuisance for period of six months after date of foreclosure).

81. Since resident owners are much less apt to abandon than those not in residence, 
redistribution should not prove regressive. ${ }^{\$ 2}$ Further, the nuisance approach may in effect transfer resources from owners to tenants. This transfer is a product of the reduction in the rate of abandonment which should result when liability is imposed on abandoning owners. Part of the reduction would be attributable to owners who remain in operation to avoid nuisance liability; ${ }^{83}$ part would be due to elimination of the "snowballing effects" of abandonment. ${ }^{8 t}$ As fewer structures are abandoned, housing which otherwise would have been taken off the market would remain available for occupation. Assuming demand does not increase, ${ }^{85}$ this stability of supply arguably should prevent the rent increases that otherwise might have ensued. This redistribution from owners to tenants also should not be regressive. ${ }^{86}$

See SteRnLIEB, supra note 1 , at 306 , they are more likely to be plaintiffs than defendants. Widespread resort to nuisance actions thus will effect a desirable transfer of resources to resident owners, who are particularly likely to take care of their properties. See id. at 74; G. Strrnlieb, The Tenement Landzord 173-76, 228 (1969); Nachbaur, supra note 2, at 18-19.

82. Although some owners may be compelled to pay damages to wealthier neighbors, there is no reason to believe that abandoning owners as a class are less well off than their neighbors. Indeed, Sternlieb's evidence would suggest the opposite conclusion. STFRnLIEB, supra note 1 , at 312.

83. An owner forced to operate at a loss probably would be unable to recover those losses by raising rents, even in an area with stable demand. Tenants would not receive any improvement in housing quality in return for the rent hike. They therefore would respond to the rent increase by moving to less expensive apartments, especially if vacancy rates were high. And indeed vacancy rates are likely to be high because of declining demand for urban housing. See note 7, supra; see also G. SterNLieb, The TENEMENT LiNDLORD 88-89, 93 (1969). The owner would be able to raise rents only if rates in his building initially were lower than those for similar buildings in the area.

84. See notes 2 \& 19 supra.

85. Such an assumption seems wartanted. The nuisance approach is largely prophylactic: deterrence of potential abandonment in an otherwise stable neighborhood is not a readily perceptible improvement. It thus should not encourage substantial in-migration. Even if the reduced likelihood of abandonment did perceptibly increase housing quality, see pp. 1145-46 stupra, it still might not be sufficient to overcome the decline in demand for urban housing. See note 7 supra. Cf. Ackerman, supra note 44, at 1140-43 (arguing that improved housing quality resulting from strict code enforcement will not inducc in-migration).

86. It is reasonable to assume that owners of urban rental housing are more affluent than their tenants. Census figures indicate that all tenants in the United States living in structures built before 1949 had a median income of $\$ 5,700$ in 1969. BUREAU of THE Cessus, 1970 Census of Holsing Supplementary Report: Income in 1969 of Families aNd Primary Individusls in OWNer and Renter Occupied Housing Units for the United Srates 4 (Ser. HC (S1)-10, Oct. 1972). One would expect individual owners to have a higher income level since they possess income-producing property. Almost half of the owners in Sternlieb's study held more than one such property. Sterncieb, supra note 1, at 60. Further, his cvidence, though inexact, seems to suggest that, at least in Newark, the median income of owners in 1964 was more than $\$ 5,700$. See id. at 312 . Many urban rental properties, moreover, are owned by corporations, banks, and governmental agencies, sec note 4 supra, a factor that apparcntly is not reflected in Sternlieb's income statistics. 


\section{Conclusion}

Programs dependent on city funding and enforcement do little to improve confidence in a neighborhood once abandonment strikes. Yet the potential of nuisance law as an alternative means of controlling the effects of housing abandonment in transitional areas has not been exploited. Steps should be taken to facilitate its use. Specifically, this Note proposes that abandoned buildings be regarded as nuisances per se and that in transitional areas injunctive relief be presumed appropriate. Thus strengthened, the nuisance approach would place an effective means of redress in the hands of those who suffer most from building abandonment. 